\title{
Peasants, agroforesters, and anthropologists: A 20-year venture in income-generating trees and hedgerows in Haiti
}

\author{
G.F. Murray ${ }^{1, *}$ and M.E. Bannister ${ }^{2}$ \\ ${ }^{1}$ Department of Anthropology, University of Florida, Gainesville, Florida 32611; ${ }^{2}$ School of Forest Resources \\ and Conservation, University of Florida, Gainesville, Florida 32611; *Author for correspondence: e-mail: \\ murray@anthro.ufl.edu
}

Key words: Anthropology, Domestication, Land tenure, Tree tenure, Project design

\begin{abstract}
This chapter examines the evolving trajectory and emerging lessons from twenty years of agroforestry project activities in Haiti that made it possible for more than 300000 Haitian peasant households - over a third of the entire rural population of Haiti - to plant wood trees as a domesticated, income-generating crop on their holdings. Unusual popular enthusiasm for the project derived from several anthropological and technical design factors: the adaptation of the project to pre-existing Haitian land tenure, tree tenure, and market systems; the elevation of micro-economic over macro-ecological themes; the decision to bypass the Haitian government and operate the project through local NGOs (non-government organizations); the use of a joint-venture mode in which smallholders supplied land and labor and the project supplied capital in the form of seedlings; the use of professionally managed small-container seedling technology rather than backyard nurseries; and a project management policy that encouraged farmer-induced deviations from project assumptions in matters of tree deployment and harvesting schedules. Issues of secure tree tenure were central to farmer planting decisions. The article discusses how secure tree tenure was possible under the heterogeneous informal arrangements that characterize Haitian peasant land tenure. The approach generated the birth of several creative Haitian peasant agroforestry configurations described in the chapter. In discussing lessons learned, the authors argue that long-term environmental payoffs should be viewed, not as the principal project goal, but as secondary side effects of smallholder tree planting decisions made for short-term micro-economic reasons.
\end{abstract}

\section{Introduction}

This chapter examines the evolving trajectory and emerging insights of 20 years of program efforts to promote tree planting and sustainable hillside farming practices in rural Haiti. The Agroforestry Outreach Project, which was launched in 1981 and continued in modified form and under different names until 2000, made it possible for over 300000 Haitian smallholders voluntarily to plant several hundred fast-growing wood trees and/or to install hedgerows on their land.

One of the authors (Murray, an anthropologist who had lived and worked in rural Haiti) was heavily involved in the initial theoretical conceptualization and programmatic design of the project and was the project 'chief of party' for the first 18 months of implementa- tion. The other author (Bannister, an agroforester) first came to Haiti as a regional coordinator for the initial project and stayed with the implementing agency, the Pan American Development Foundation (PADF), for most of the two decades in which the project continued. An unusually heavy level of interdisciplinary collaboration between agroforesters and anthropologists was a key feature of the project in its initial years.

The protagonists in the tree saga, however, are neither anthropologists nor agroforesters but the smallholders of Haiti, inhabitants of a nation with troubling economic, political, epidemiological, educational, and ecological indicators. The doom-andgloom tone that dominates international discussions of Haiti began long ago. Indeed the entire Caribbean 
island of Hispaniola has had a tragic demographic history, beginning with the death of as many as one million Amerindians, in the early sixteenth century, largely from European diseases, and followed by their replacement with half a million African slaves coerced into what was the most prosperous but the harshest of New-World slave regimes. In 1804, after 13 years of revolutionary bloodshed, the French colony of SaintDomingue was renamed Haiti, as the first independent nation of rebel ex-slaves was born, (Rogozinsky 2000).

Two centuries later more than 8 million Creolespeaking descendants of these rebel slaves are crowded into the mountainous western third of Hispaniola, tensely sharing the island with 8 million more prosperous Spanish-speaking Dominican neighbors to the east. Ecologically Haitians inherited the 'wrong side' of the island. Haiti's surface area of 27750 sq. $\mathrm{km}$. has few fertile lowland plains. Most of the country is mountainous and $75 \%$ of the country would be classified as sloping highlands (Weil et al. 1973). Limestone substrate underlies $80 \%$ of the land area; the rest is basaltic or alluvial (Ehrlich et al. 1985). The country's thin subtropical topsoils, vulnerable to start with, long ago succumbed to erosion under landuse systems based not on the practices of unknown African ancestors but on the extractive technologies of a market-oriented colonial plantation system.

Tree cover has virtually disappeared. An application of Holdridge's (1947) classification showed a country whose 'life zones' consisted of subtropical moist forest and subtropical dry forest, subtropical wet and rain forest zones being common in the middle and upper elevations. Half a century later, however, the few forests that remained in the 1940s have now virtually disappeared. The few autochthonous treeplanting traditions that emerged in post-revolutionary Haiti tended to focus on fruit trees. Wood trees, in contrast, were viewed as natural goods supplied by nature - or rather by Bon-Dye, the Creole version of the French word for God - for human extraction. Though some individual wood trees were considered sacred and left standing, protective folk religious traditions were ecologically impotent in the face of a growing rural population that needed to clear land for farming and a growing urban population that needed charcoal as cooking fuel. In short, its troubling economic and social statistics, its political chaos, and its denuded hillsides make Haiti an unlikely setting for a happy tree story.
The earliest reforestation attempts were emphatically not happy stories. They began under foreign prodding with the arrival of development agencies after World War II. These early projects were largely based on the theme of reboisement, protectionist and conservationist reforestation premises inappropriate to a virtually treeless but densely inhabited country. Furthermore international donor funds were routinely entrusted to the fiscal management of predatory and mistrusted state bureaucracies whose authoritarian commands to plant and protect trees were routinely ignored by villagers and whose foreign-funded seedlings therefore died in nurseries for want of interested planters.

Some three decades of tree planting failures led frustrated expatriate donors, by the late 1970s, to be open to new paradigms. It was at this period that the United States Agency for International Development (USAID) contracted anthropologists to propose new models. The result was the Agroforestry Outreach Project, and its successor descendants, to be described here. The approach was based on several factors, including (1) the adaptation of the project to pre-existing Haitian land tenure, tree tenure, and market systems, (2) the elevation of micro-economic over macro-ecological themes, (3) the decision to bypass the Haitian government and operate the project through local NGOs (non-government organizations), (4) the use of a joint-venture mode in which smallholders supplied land and labor and the project supplied capital in the form of seedlings, (5) the use of professionally managed small-container seedling technology rather than backyard nurseries, and (6) a project management policy that encouraged farmer-induced deviations from project assumptions in matters of tree deployment and harvesting schedules.

\section{Information sources}

To go beyond personal anecdotes, we will base our description of the approach and our analysis of its results on a now voluminous literature from Haiti, which includes over a dozen empirical studies of Haitian smallholders who planted wood-trees on their holdings in the course of the project. The research scrutiny given to one project has been quite unusual. Pre-project feasibility investigations include Murray $\left(1979^{1} ; 1981^{2}\right.$ ) and Smucker $\left(1981^{3}\right)$. Two years after the project started Murray published the first description of the project (Murray 1984), followed by an analysis fo- 
cusing on anthropological issues (Murray 1987). A project agroforester returned to villages where he had delivered trees three years earlier to examine their fate (Buffum 1985'; Buffum and King 1985 ${ }^{5}$ ). One anthropologist wrote his doctoral dissertation on the project (Balzano 1989). Another anthropologist examined decision-making processes in a community of early tree planters (Conway 1986a ${ }^{6}$ ) and synthesized the results of five additional studies of tree-planting communities done under the auspices of either PADF or the University of Maine, a project research partner (Conway $1986 b^{7}$; Lauwerysen $1985^{8}$ ). An economist calculated monetary returns to tree planters and documented higher-than-predicted internal rates of return $\left(\right.$ Grosenick $\left.1986^{9}\right)$. Another economist examined the charcoal and pole markets (McGowan 1986 ${ }^{10}$ ), and Smucker $\left(1988^{11}\right)$ analyzed six years of tree planting in several communities. In the early 1990s, Bannister and Nair (1990) discussed the soon-to-be expanded hedgerow component of the project, and Bannister and Josiah (1993) examined extension and training issues. An anthropologist/forester team (Smucker and Timyan $1995^{12}$ ) did case studies that included harvest information. The following year Timyan (1996) published a volume on the trees of Haiti. Land-tenure issues were analyzed by Smucker et al. (2002). Most recently Bannister and Nair (2003) analyzed data from 1540 households and 2295 plots that had received project interventions. There is, in short, a substantial body of empirical information provided by anthropologists, agroforesters, and economists from which we will draw.

In terms of secondary literature, the project has received more attention in the professional circles of anthropology than those of forestry or agroforestry. Two years after its onset, it won the international Anthropological Praxis Award, a competitive annual prize for applied anthropology. The project is now one of the most frequently cited cases of applied anthropology in recent college cultural anthropology textbooks (e.g., Robbins 1993, Nanda and Warms 1998, Peoples and Bailey 1997, Ferraro 1998, Harris and Johnson 2000). A description of the project has been reprinted in four successive editions of a widely circulated reader in applied anthropology (Podolefsky and Brown 1989). We have come across only one anthropological critique of the project (Escobar 1991), whose author had not been to Haiti but who excoriated this and several other anthropological projects for the sin of "commodification', i.e. opening the 'natural systems' of peasants to the 'penetration of capital' and exposing peasants to the perilous world of markets and money. (This romantic but poorly conceived desire to protect smallholders from access to money would meet with little sympathy among intended peasant protégés anywhere in the world).

The project has received much less attention, however, in what may be its most proper professional habitat, the world of agroforestry. In this article we will therefore focus on issues germane to agroforesters.

\section{Projects as evolving systems}

We will proceed systemically rather than anecdotally. Agroforestry configurations are best viewed, not as a collage of discrete practices, but as dynamic, evolving, integrated systems. By the same token, externally funded projects themselves are best viewed as evolving, problem-solving systems. We propose that, whatever culture-specific idiosyncratic arrangements may be instituted in different countries, the typical agroforestry project nonetheless has four universal or quasi-universal underlying problem sets to solve: technical planning, benefit-flow planning, fund management, and village outreach strategies. We will examine the Haiti project through the lens of these four broad systemic components.

\section{Technical base}

For market-related reasons discussed in Murray (1987) the planting of wood was a better incomegenerating venture in Haiti than the planting of fruit. The project therefore focused on the distribution of wood tree seedlings. Because of the limited inventory of existing small-container tree nurseries in Port-auPrince, the project began with six exotic fast-growing hardwood species: Acacia auriculiformis, Azadirachta indica, Casuarina equisetifolia, Eucalyptus camaldulensis, Leucaena leucocephala, and Senna siamea. By the end of the project twenty years later farmers were planting 74 species, many of them local trees. As we shall see below, the farmers supplied land and labor. The project supplied several hundred seedlings free of charge to each participant.

Both for quality control and economies of scale, the project opted for professionally run nurseries rather than backyard nurseries or direct-seeding techniques. At the apogee of the tree planting component in the late 1980s the project was being supplied by 36 nurseries producing nearly 10 million seedlings a 
year all over Haiti. The nurseries were not owned by the project. NGOs (non-governmental organizations) operated the nurseries as profit-generating microenterprises. Villagers who had been contracted as tree extensionists would elicit orders for quantities and species of wood seedlings among their kin and neighbors. The nursery would produce and sell the seedlings to PADF at an agreed on price. PADF would then organize the distribution of seedlings. To facilitate transportation the nurseries used small containers rather than polyurethane bags. Backyard nurseries with polyurethane bags were experimentally introduced in the late 1980s, and increased in the 1990s.

To enhance the soil conservation element, the second author began experimenting with Leucaena leucocephala hedgerows in 1984. Extension of treebased soil conservation structures was officially adopted by the project in 1987, but after 1991 it became the dominant project element. Because of marketing weaknesses, fruit trees had been a minor component of the project in its earliest years. This component, however, increased dramatically in the project's second decade, including top-grafting of adult fruit trees. A new component, improved food crop germplasm, was introduced in the 1990s. The logic of this new agricultural component was that plots protected by some form of soil conservation would eventually become more fertile, and therefore would merit a larger investment in crop production.

\section{Benefit flow arrangement}

Agroforestry projects cannot limit attention to technical matters. The resolution of a second problem set, the guaranteeing of satisfactory benefit flows is equally essential to project acceptance. We assured benefit flows by sharing costs and risks with farmers and by guaranteeing their total control of harvesting and marketing. We established a joint venture arrangement in which participants supplied two of the factors of production - land and labor - and the project supplied capital in the form of seedlings. Participants would risk covering part of their land with a new crop - the wood tree - and plant enough to make a measurable economic difference down the road. As for labor, we broke militantly with the 'Food-for-Work' subsidy that had been used in most previous tree-planting projects. Participants had to supply all of the ground preparation and planting labor, either by doing it themselves or by using one of the many labor-mobilizing arrange- ments (e.g., exchange labor with neighbors) found in traditional Haiti.

As for capital, the project supplied it in the form of several hundred free-of-cost wood seedlings to each participant. The original minimum of 500 seedlings was quickly dropped to 200 seedlings and eventually even less. The project was having difficulty supplying the unexpected demand which it provoked, and labor constraints (more so than land constraints) made it difficult for many farmers to plant 500 seedlings at one fell swoop, since the planting of seedlings had to be timed with rains, which was the trigger for planting other crops as well. Each seedling cost about 10 U.S. cents to produce. The project thus made a modest average contribution of about $\$ 20$ in seedlings to each participant, who in turn allocated land and labor. We recommended different planting strategies, but planters made the final seedling-deployment decisions. Of major importance, we guaranteed tree tenure and full harvest rights. We repeated regularly that planters would be sole owners of seedlings and trees. Villagers needed no permission to harvest trees. In the second decade, other benefit flow arrangements were instituted for hedgerow and improved food-seed components.

\section{Fund management arrangements}

Besides a solid technical base and well-designed benefit flows, projects have a third challenge: fund management. Had funds been entrusted to the Haitian government, we would be doing a post-mortem on why the project failed. The money was managed, instead, by PADF, the implementing NGO, utilizing an ad-hoc 'umbrella strategy' of grant management that was devised specifically for the project. USAID made a macro-grant of $\$ 4$ million - i.e. $\$ 1$ million per year - to PADF. PADF then entered into agreements with local NGOs all over Haiti to hire and train village tree agents who in turn would invite their kin and neighbors to plant trees on their own land. PADF's support to these groups was in the form of contracts that included in-kind seedlings and small amounts of cash for overhead, salaries of promoters, and other minor expenses. This umbrella strategy permitted one central macro-grant to feed hundreds of localized minicontracts. It was a welcome buffering mechanism appreciated by all parties. USAID staff had to manage only one grant. Local NGOs were shielded from stringent USAID accounting requirements. 


\section{Outreach structures}

A fourth universal agroforestry problem-set is outreach. Local NGOs selected and hired villagers to serve as tree extensionists. These villagers, trained by the project and compensated on a part-time basis by tasks performed, would explain the project to their kin and neighbors and invite them to allocate part of their land and labor to wood tree seedlings over which, once planted on their land, they were guaranteed total ownership and harvest rights. As nursery seedlings matured and rains arrived, the seedlings, which were grown in commercial organic potting mixes that guaranteed good root development, would be removed from the containers, placed in boxes, and loaded on pickup trucks. Villagers were pre-alerted and plots were prepared. Participants gathered at designated drop-off sites and received their seedlings. Seedlings were generally in the ground 48 hours after pickup. Similar outreach structures were employed in the second decade for hedgerow and improved crop promotion. During the second ten years of the project (beginning in 1992) there was a shift from larger NGOs to smaller community-based organizations (CBOs) and the strengthening of farmer groups became an important goal.

The project measures just described are presented, not as a cookbook recipe to be applied elsewhere, but as an abstract project paradigm that may be generalizable beyond Haiti. The four problem sets addressed in the Haiti project will have to be addressed in many and perhaps most projects around the world: (1) technical decisions, (2) benefit flow arrangement, (3) fund management, and (4) outreach. Different specific solutions will apply in other world regions. But the problem-sets themselves are widespread if not universal. ${ }^{13}$

\section{Qualitative results: evolving agroforestry micro-systems}

We have more research information on the results of the tree component than on the later hedgerow component. The PADF component alone ${ }^{14}$ tripled its projected seedling output in the first four years. And the 65 million seedling figure for two decades, all voluntarily planted in small lots of several hundred or fewer by over 300000 peasants on their own holdings, leaves absolutely no doubt as to the enthusiasm generated by the project for the planting of wood trees in a country where they were formerly extracted from nature.
These figures by themselves, however, reveal little about the character of the agroforestry systems that emerged. Enthusiasm seemed homogeneous, but not specific tree-deployment decisions. The creativity of diverse local responses produced a rich heterogeneity of agroforestry configurations. They have been descriptively documented in several of the studies cited in the Introduction section. We will describe the systems as a series of questions.

\section{Who planted project wood trees, who did not plant, and why?}

Several studies (among them Conway $1986 a^{6}$; Balzano 1989; Bannister and Nair 2003) explore statistical links between tree planting as the dependent variable and personal or household variables as independent variables governing tree-planting decisions. Socioeconomic differentials and gender are two particularly interesting clusters of independent variables.

Haitian villages are not homogeneous; modest socioeconomic differentials exist. A 5-hectare holding would be 'large'. The national holding mean is closer to 1.5 ha (Zuvekas 1979). Balzano $\left(1986^{15}\right)$ documented a slight statistical tendency for tree-planters to be older, to have slightly more land under secure tenure, and to be in a better position to hire labor. Similar findings were found to hold as well more than a decade later in Bannister and Nair (2003). Though statistically significant, however, the cross tabs and correlations using household and plot characteristics as predictors explain only a small fraction of the differences between planters and non-planters, or between heavier and lighter participation. The project hope of reaching even land-poorer sectors was attained. (Total landlessness is rare in rural Haiti.)

As for gender, trees were offered to females as well as males. In the project's final year, 135436 males and 41121 females $(23 \%)$ were listed as participants. These figures warrant explanation. The gender skewing reflects local customs of formal household headship. In households with a conjugal couple the male traditionally presents himself as household head and was listed as the project participant. Female participants are generally from households headed by a female. Even in households with a conjugal couple, however, case studies (e.g. Smucker and Timyan $1995^{12}$ ) have shown that wives of participants were heavily involved in household decisions whether to plant or not to plant and in the subsequent management of the plantings. 


\section{For what purposes did peasants plant trees?}

The stated goals of tree planters in all studies were overwhelmingly economic. The dominant goal was harvest of the wood, precisely as had been predicted in the anthropological 'social soundness analysis' (Murray $1981^{2}$ ) that formed the conceptual backbone of the original USAID project document. The definition of 'economic', however, had to be broadened. Murray (1984) alluded to the themes of 'cash cropping' and the 'domestication of energy' (e.g., of charcoal) as central to the project in the first article published on the project a year and a half into its implementation. The prediction was that the project would permit a shift from the then prevalent extractive mode of charcoal procurement. Balzano (1989) and Smucker and Timyan $\left(1995^{12}\right)$ give case study evidence of farmers in some regions behaving exactly as predicted, planting jaden chabon, 'charcoal gardens'. They would prepare a field, plant it with annuals, intercrop wood tree seedlings, continue cropping until shade competition from the trees no longer permitted, clear cut the growing trees, convert the wood into charcoal, and begin again.

But these were the exceptions. More farmers planted with a view to more valuable saw-timber further down the road. And few harvested all of their trees at once. They used the tree rather to store value, less vulnerable to drought than annual crops (cf. Conway $1986 a^{6}$; Smucker and Timyan $1995^{12}$ ). In some regions farmers calculate a $50 \%$ probability of losing one's annual food crop to drought. Under such conditions of agrarian peril the domestic tree stand becomes an economic safety net that is protected until absolutely needed, and even then cut only selectively. Balzano ${ }^{16}$ revisited his dissertation community 10 years later and found large number of project trees still standing, some of them over $15 \mathrm{~m}$ high, being protected as vehicles of savings for times of emergency.

But farmers' harvest decisions reminded us further to broaden the term 'economic' beyond money. We have observed tree planters for the first time in Haitian history 'growing' parts of their houses, particularly posts and rafters. No cash is generated in such selfuse; but money is saved. Self-use is more frequent with poles and beams than with charcoal and timber, probably because of clearer price-setting dynamics for low-valued charcoal and high-valued planks (McGowan1986 ${ }^{10}$; Smucker and Timyan 1995 ${ }^{12}$ ). But whether marketed or used for one's own house, the motivation is economic. The trees did provide ecological benefits to the fields as well (Grosenick 1986 ${ }^{9}$ ). Exactly as was predicted in pre-project documents, however, ecological benefits from trees came as secondary side effects of behaviors in which smallholders engaged for economic reasons.

The primacy of economic motives came out dramatically even in the most heavily ecological component of the project, contour hedgerows. In theory, peasants were to top-prune hedgerows to about $50 \mathrm{~cm}$, use the leafy material as a soil amendment in the alleyways, and the cut woody material as a soil-retention barrier uphill from the hedgerow. In actuality, peasants were more prone to using the leafy material as fodder for livestock rather than as fertilizer in the soil. In other words economic payoffs from well-fed goats were viewed as more attractive than the ecological advantages of well-fertilized land.

But farmers' economic maneuvers went even further. They invented a new type of hedgerow consisting of perennial food crops (especially plantains (Musa spp.), sugar cane (Sacharum officinarum), cassava (Manihot esculenta), pigeon peas (Cajanus cajan), and pineapple (Ananas comosus)) as the structural component, holding the soil, in combination with annual crops (particularly sweet potato (Ipomoea batatas), yam (Diascorea spp.), and others) grown underneath them in a wider contour band whose width could reach 2 or $3 \mathrm{~m}$ up and down slope (the width of the typical hedgerow is a meter). The name of this new invention was bann manjé - a play on words that can mean 'a band of food' or 'a bunch of food'. The bulk of the food on the bann manje was destined for sale in markets. What the peasants of marketoriented Haiti were doing was in effect converting what technicians had intended to be a conservation and fertility-enriching strategy - i.e. an ecological strategy into a microeconomic income-enhancing strategy (cf. Ashby et al. (1996) for similar behaviors in Colombia. Bunch (1999) also found Central American farmers independently modifying project-promoted conservation structures. Garcia et al. (2002) discuss evolving hedgerow technologies in the Philippines.)

\section{Site management strategies: Where did they plant} trees?

The question can be subdivided into holdingmanagement and plot-management issues. On which plots, within the typical Haitian multi-plot holding, were trees planted? And where were trees deployed 
within the selected plots? As for the former, several research documents identify three variables that governed plot selection: land tenure, distance from the home, and the edaphic/ topographic characteristics of the plot itself.

With respect to land tenure, pre-project predictions hypothesized that farmers would plant principally on the two types of plots over which Haitian villagers have reasonably secure control: plots which they have purchased, and plots that they have inherited and subdivided among siblings. Rarely is the subdivision done with a fully legal surveyor's chain. It is almost universally done with ropes in the presence of community witnesses. The separation is informal rather than legal. But once that subdivision occurs with community witnesses, the recipient is the de-facto owner and can safely plant trees. It was conversely predicted that smallholders would be less inclined to plant trees on sharecropped land, on rented land, and on undivided inheritance land over which they had no exclusive control. These predictions were borne out strongly in the studies of several tree-planting villages done in the mid 1980s, several years after project launching, by Buffum $\left(1985^{4}\right)$, Lauwerysen $\left(1985^{8}\right)$, Balzano $\left(1986^{15}\right)$, and Conway $\left(1986 a^{6}\right)$. Smucker and Timyan $\left(1995^{12}\right)$ also pointed out that the functionally important variable is not legally deeded ownership of the plot (which is extremely rare) but rather secure control over the trees, which can be acquired through informal land ownership. Purchased and subdivided inheritance plots are recognized by the community as 'owned' by farmers even in the absence of surveyed deeds. Such de-facto control is required for secure ownership of the trees planted. The ownership of the tree is, in fact, the key variable predicting willingness to plant. The statistical analysis done by Bannister and Nair (2003) confirms the same tendency for more trees to be planted on plots under more secure tenure.

Exceptional cases were found on which even sharecroppers or managers could work out tree planting arrangements with the owners. But the pre-project predictions about the importance of land tenure as a determinant of tree planting were fully borne out. The project was therefore possible in Haiti, where smallholdings may be the norm but landlessness is rare. In countries with large landless sectors special project measures will be required to avoid favoring only the well-off with privately owned trees.

A second variable, distance from the home, also played a role in plot selection. The result was the planting of project trees closer to home. Soil-quality and slope variables also played a role (Bannister and Nair 2003). Trees were rarely planted in any numbers on precisely the plots that outsiders would deem the ideal site, heavily sloped and eroded agriculturally marginal plots where crops cannot grow but where wood trees could, albeit slowly. Trees tended to be planted on agriculturally better land in conjunction with food crops.

This tendency to avoid distant and degraded plots is fully logical but economically and ecologically unfortunate. The logic is that farmers are aware, much more than planners, that trees in Haiti are vulnerable to three dangerous predators that can wreak havoc on distant plots or agriculturally marginal plots: (1) free ranging livestock, (2) nocturnal thieves, and (3) one's own kin. On plots distant from one's home, young seedlings are more vulnerable to free browsing livestock, and mature trees can be and were cut by thieves. And as for the agriculturally marginal denuded hillsides all over Haiti that would be prime candidates for hardy trees, it is precisely such land that kin groups keep in common for grazing purposes. There is no individually recognized owner of any particular plot.

If seedlings are planted on this collective land, and if the seedlings miraculously survived the free-ranging goats, a distant cousin of the planter could harvest the wood and would not have to do so under cover of darkness. The issue is tree tenure. The tree is not safely yours unless the land on which it stands has been subdivided by common informal agreement. And even when the tree is on your land, you will come under pressure from kin to give them permission to cut some of your trees. Wood was traditionally a free good and, though now planted, retains its earlier 'communal' aura. Relatives might never dream of asking you to let them harvest part of your bean crop. But they can and do ask you to let them cut some of your planted wood.

These three predatory actors - livestock, thieves, and relatives - generate an economically and ecologically formidable barrier to the expansion of tree planting onto precisely the underutilized plots where the competition from trees would be lowest and the economic increments from wood would be greatest. The problems will all be solvable at a more advanced stage of the transition to planting wood. Kin groups and communities can make arrangements to neutralize each of the three predators and to make tree planting possible on these marginal landscapes. The present project, however, merely observed the barriers, without being able to circumvent them. 
The result was a strong tendency to plant project trees in conjunction with one's plots, which is precisely the arrangement envisioned in classical agroforestry. The agroforestry configurations that did emerge on agricultural land and on house sites were rich in their diversity. The preferred strategy was to convert the border of the plot into the principal locus of the trees. And no clear-cutting is generally performed on these trees. They are kept rather as a permanent source of wood, to be harvested selectively as needed. Many trees were also planted near the homestead.

In some cases plots were allowed to evolve into permanent woodlots. On agricultural land more distant from homesteads, farmers often place agrarian risks on sharecroppers. As a general rule, however, the sharecropping arrangement impedes tree-planting. Barring exceptional arrangements, the tenant will not plant trees as he will probably not be the one to harvest them. The landowner will not plant, as the sharecropper will take subtle measures to eliminate them. One arrangement observed was for the landowner to designate a block of land on one edge of the plot for a permanent woodlot whose vegetation belongs to him, not to the tenant. Since the tenant cannot plant there, there is no incentive to help the seedlings die. In one reported case (Smucker and Timyan $1995^{12}$ ) the household derived more benefits from the woodlot in the form of charcoal and pole wood than it did from the portion of the meager harvest that they received on the sharecropped part of the plot.

In a small number of cases even entire plots with at least some agricultural potential have been allowed to evolve into permanent woodlots. But this is done for exceptional reasons - the owner may be aging and may have less energy for agrarian pursuits, or may migrate temporarily to the Dominican Republic and can get more from the land by turning it over to low-maintenance trees. This is not done with enough frequency to cause a cut in local food supplies.

\section{How many seedlings survived the first year?}

The entire undertaking, of course, is an exercise in futility if the seedlings die. Survival- monitoring procedures were instituted by PADF. An increasing 12-month tree survival rate was achieved as the project progressed in its first decade from an early project average hovering near $30 \%$ to a later average closer to $50 \%$. Data are not available for seedling survival during the more intensive 1990s phase. Because of closer interactions between project and participants, the survival rates were probably higher. A reasonable generalization, at least for Haiti, would be that in a project of this type, in which seedlings are transplanted onto farmer-controlled rather than project-controlled plots, approximately two seedlings will be required for every mature tree.

\section{When were the trees harvested?}

The timing of tree harvest is determined less by agronomic perceptions on the part of the peasant, e.g., the mean annual growth increment, than by special crises or special occasions in which expenditures are required: funerals, illnesses, weddings, school tuition. In this sense peasant treatment of the tree is quite different from what is done in developed industrial plantations. This cutting-in-crisis is not erratic shortsighted behavior on the part of the peasant. It is part of a long-term strategy in which the wood tree becomes a partial surrogate for the savings that used to be achieved principally through livestock raising.

A negative theme that recurs in the case studies is the obligation that farmers felt to accelerate wood harvest. The initial objective was often the harvest of timber, the highest value of wood trees. In some communities studied (Conway 1986a ${ }^{6}$ ) few if any participants reported planting with a view to the charcoal market. But economic pressures often lead to faster cutting of the trees for charcoal.

The harvest schedule of wood trees, because it is so discretionary, is much more vulnerable to political events than is true of other crops. Rice (Oryza sativa) and beans (Phaseolus spp.) have to be harvested on schedule, whatever happens in national and international politics. Not so trees. But the political chaos following the ousting of a dictator in 1986 increased lawlessness and thievery. A U.S. embargo of the 1990s, instituted after an elected president was ousted in a coup, created hardships that led to premature harvest of the trees. Political events thus accelerated tree harvesting, as tree-owners switched from timber to charcoal goals either to meet urgent cash needs or to protect against the clandestine cutting of trees by thieves.

\section{What happened to the plots after tree harvest?}

There are no case studies that document a post-harvest 'good riddance' attitude on the part of farmers. What the case studies, particularly those of Smucker and Timyan $\left(1995^{12}\right)$, show is the emergence, as a result of project participation, of a transformed land orientation 
in which the wood tree is now seen to be a danre, an income-generating crop that can be planted like other crops. The post-harvest replacement strategies entail careful managing of coppice and transplanting of wildlings. If seedlings are made available farmers will replant and even expand tree-planting into new areas of their holdings. Internal attitudes and external behaviors toward the wood tree have been profoundly modified, not through educational messages and not through ecological homilies, but through planting and harvesting.

\section{Quantitative indicators}

\section{Tree seedlings}

If the project had reached only 10 communities and 300 families, the preceding descriptions of emergent agroforestry orientations would still make it humanly and scientifically interesting. But it reached hundreds of thousands of families. During the first 10 years (1982-1991), when large-scale tree distribution was the main focus, about 48 million wood tree seedlings were distributed to farmers by PADF alone. In the project's second decade, from 1992 to 2000, the PADF component of the project delivered 14 million seedlings. An additional three million seedlings were produced during this second decade by farmer-operated, small, 'plastic bag' nurseries.

In spite of the dwindling in average annual seedling output during the second decade (for extraneous reasons to be discussed later), a total of 65 million seedlings, over $95 \%$ of them wood tree seedlings of 74 different autochthonous and exotic species, were voluntarily integrated by Haitian peasants onto their own holdings during the project's 20 years through the PADF project. CARE (Cooperative for Assistance and Relief Everywhere, Inc.) was also active in tree-planting activities in Haiti's arid northwestern region during this period under the overall USAID project. Although we lack precise data on such CAREsponsored tree-planting, a conservative estimate of the total project-facilitated out-planting is over 100 million trees on Haitian peasant land during the 20-year period.

\section{Hedgerows, gully-plugs, and other soil conservation interventions}

During the first decade of the project, soil conservation interventions were minimal. Six hundred fifty (650) $\mathrm{km}$ of hedgerows were installed, and 2200 gully plugs were built. In the second decade, with its shift into a greater emphasis on conservation practices, farmers installed over $12000 \mathrm{~km}$ of hedgerows, $3000 \mathrm{~km}$ of rock walls, and 94000 gully plugs. In addition, the 'agro' component of agroforestry was increased, and improved food-crop germplasm was distributed to cover over 11000 ha of land, and 30000 vegetable gardens were planted.

\section{Numbers of participating smallholders}

Such aggregate tree and hedgerow statistics by themselves meant nothing to project implementers. If the 65 million trees planted had all ended up on State land or on the land of 500 wealthy landowners, the project would have been seen as a failure. As Nair (1993) points out, agroforestry is not merely about biomass. It attempts to benefit the rural poor as well. For us, the key statistic in the Haiti project is not number of seedlings distributed but number of households participating.

During the first 10 years, two factors confounded the counting of real participants. About a third of the participants in any season may have been 'repeatplanters', not new ones. But there was even stronger skewing in the opposite direction in the form of 'nonregistered participants'. It is known that many farmers receiving 200 or 300 seedlings would distribute a substantial but impossible-to-quantify number to relatives or friends, who thus became de-facto - but uncounted - project beneficiaries. A conservative estimate of numbers of distinct households planting the 48 million seedlings distributed during the first decade would be 190000 households, or about 250 seedlings per household. During the final eight years, 1992-2000, when the project concentrated in smaller geographic areas, the data are more precise. A total of 176557 farmers are known to have participated through 83 local organizations that employed about 1000 extensionists. To accommodate the possibility of up to $15 \%$ of nonregistered planters, a recent article by Bannister and Nair (2003) raise the figure to 200000 participants for the second decade. That means a total of 390000 households for the two periods. Conservatively, we can state with confidence that during its 20-year life the project involved a minimum of 350000 Haitian farm families.

When placed in the context of Haitian demography, these figures startle even the most enthusiastic proponent of the approach used. The population aver- 
age for the 20-year period can be set at 6 million, about $70 \%$ (or 4.2 million) of whom were living in rural areas. Survey data carried out by the second author yielded an average of 5.7 persons per rural household. If extrapolated to all rural areas, there are about 737000 rural households in Haiti. With the project reaching a minimum of 350000 households as stated above, more than $40 \%$ and perhaps nearly $50 \%$ of the households of rural Haiti may have received seedlings or otherwise participated in the project at one point or another during the two decades. Even if these national participation figures are dropped by 10 or even 20 percentage points for 'safety's sake', the level of nationwide involvement in and enthusiasm for a tree planting project must still be seen as unprecedented in the annals of agroforestry.

We cite these figures, not to tout the 'success' of the project. Success must be evaluated on criteria that go beyond crude number crunching. We consider the qualitative descriptions of emergent agroforestry systems presented in the preceding section to be better indications of the effectiveness of the approach. The national statistics reveal less about the project than about the peasants, or rather about the potential for the emergence, certainly in Haiti and possibly elsewhere, of an evolutionary restructuring of the relationship between the smallholder and the wood-tree. If the poorest farmers, with the smallest holdings, of the Western Hemisphere, can be moved by anthropologically and technically creative project design and by an abundant supply of high quality seedlings - to incorporate wood trees into their agrarian inventory, the potential for smallholder tree planting must be even greater in economically less-stressed settings. Stated differently, there was a latent readiness in Haiti for a shift into massive wood-tree planting, a type of subterranean 'potential energy' waiting to be released. A well designed project that deals with issues of tree tenure, harvest rights, and (above all) seedling supply can act as a catalyst to convert this potential energy into kinetic energy - to convert interest in trees into the planting of trees.

\section{Generalizable lessons?}

We have learned lessons in Haiti. Their generalizability to other settings, however, is a matter for professional debate. Let us simply conclude by briefly ventilating several controversial issues, each of which by itself warrants an article. Four of them, we be- lieve, have been settled, at least for Haiti. Two are still contested.

\section{Economic vs. ecological goals: The Neolithic analogy}

The project entailed a paradigm shift for both planner and peasant in their view of the wood tree. Earlier project planners, with themes of reforestation and conservation, viewed the wood tree as a natural resource to be protected. Haitian villagers also treated it as a natural resource, but one to be exploited, not protected. The project moved militantly away from any such 'natural resource' construal of the tree at all. We presented the wood tree instead as a slow-growing crop that could be planted, harvested, and sold or used as any other crop. Villagers made the shift in their own way, usually treating their trees not as a crop to clearcut in one fell swoop, but as a store of value to slowly harvest when needed. But the shift into a domesticated mode of wood production was made by a substantial percentage of the population of rural Haiti.

As Murray (1987) pointed out, there were ancient anthropological precedents for this shift into domestication. Archeologists and cultural anthropologists have studied that ancient food crisis in the Fertile Crescent that led some 12 millennia ago into the shift away from dependence on the gathering of wild vegetation and the hunting of wild animals into the domestication of crops and livestock, a process referred to as the Neolithic transition. The shift was provoked by food shortages, by 'Paleolithic overkill' of wild animals. This food crisis was not solved, however, by 'natural resource management', by better stewardship of nature's resources, or by a shift to 'sustained yield' hunting and gathering. It was solved instead by $d o-$ mestication, by a shift from an extractive mode to a productive mode of resource procurement. Gathering of wild vegetation yielded to crop cultivation, hunting to livestock. (Murray 1987; cf. Simons and Leakey 2004).

Parallel problems evoke parallel solutions. The shift into a domesticated mode of wood production is a replay in the domain of wood of the process that led to the domestication of food. The evolutionary readiness of Haitian villagers to this alternative emerged because two of three conditions were already present in local economic repertoires. (1) The cash-cropping farmers of Haiti had been planting for markets for nearly two centuries. (2) Increasing wood scarcity and burgeoning construction and charcoal markets endowed wood with more commercial value than most annuals. The 
missing connection was the planting of the wood to be cut and sold. Once a seedling supply had been established, however, and tree tenure had been guaranteed, the shift from extracting wood for sale to planting and harvesting it for sale was a logical, gentle step, and an attractive alternative to explore (Murray 1987).

Rational farmers dealing with real problems easily make the shift into a new paradigm. Whether planners and intellectuals can make the shift $-\mathrm{a}$ focus on messages of domestication and production or whether they will cling to archaic protect-MotherNature paradigms, is another question. If the Neolithic analogy holds, the wood crisis on planet earth is more likely to be solved by the production of planted wood, as Haitian villagers have begun doing, than by the protection of nature's wood.

Let us not push the analogy too far; Amazonian and Orinoco rain forests can and should be protected. But let us conversely desist from infecting tree programs in settings like Haiti with inappropriate protectMother-Nature conservationist themes. The woodlot planted by a farmer is no longer a 'natural resource'. It is a crop. The natural tree stands of Amazonia should be hugged and protected. The domesticated tree stands of rural Haiti should be hugged and then harvested.

\section{Professional nurseries vs. backyard nurseries}

When the anti-subsidy policy in USAID led to the closing of NGO nurseries in 1991, the tree component of the project had to shift to backyard nurseries operated by individual farmers or small groups. The subsidies were just as great; polyurethane sack containers, seeds, and watering devices were supplied by the project. But they were masked under a camouflage of grassroots thatched-shed 'peasant initiative' that the anti-subsidy vigilantes lacked either the talent or inclination to penetrate. These peasant-managed backyard nurseries, however, should not be romanticized as more sustainable or developmentally superior. Their volume of output was lethargic compared to that of professionally run small-container nurseries. And the $80 \%$ subsidy that nurtured them is no more sustainable than the $100 \%$ dependence by NGO nurseries on project purchases.

Several arguments can be made in favor of the professionally run nursery. Sixty five million seedlings distributed to Haitian farmers were incorporated as crops into their farming systems. A responsibility comes with this level of output - to ensure a sustainable source of the best quality tree seeds possible.
The NGO nurseries established with project assistance purchased most of their tree seeds from PADF, who imported some of them from overseas suppliers and collected the others locally using local entrepreneurs who were given some training in what characteristics to look for. The nurseries also collected seeds themselves from their regions.

The difficulty with seed supply in Haiti is that trees with the most desirable characteristics were harvested long ago, leaving the inferior individuals to supply seeds, with the resulting drop in production. Even more troubling is that seed of some of the popular exotic species, such as Senna siamea, Azadirachta indica, and Swietenia macrophylla, were collected from a very small number of parent trees planted near government buildings. This makes for a very narrow genetic base for a large population of trees. Since resistance to pests and diseases is a highly heritable trait in trees, this genetically narrow population could be at risk. In any case, a broader genetic base of tree germplasm is necessary to support future selection for increased production, ability to grow in marginal sites, and improved growth rate (Zobel and Talbert 1984). A tree seed selection program was begun by the project in the late 1980s with large private landowners to establish selection trials that would eventually be converted to seed orchards (J. Timyan, pers. comm. September 2003). In short, professionally managed seed and seedling operations have clear advantages over the backyard user-managed nursery in these matters. And in terms of seedling quality, volume of production, and the ability to excite farmer enthusiasm, the professionally run NGO nursery was a better seedling-supply option than the backyard nursery in Haiti.

\section{Public vs. private fund management}

A third matter has been 'settled', at least for Haiti. In the absence of functioning government institutions, the NGO route was selected for project administration. Cordial working relationships were eventually established with local government agronomists. But at no time did the Haitian government control any project funds.

The NGO mode of project implementation does not sit well in all international development circles. One concern is the issue of local State sovereignty in development matters. Another is the fly-by-night, predatory behavior of at least some NGOs. The respect-sovereignty anthem, however, rang flat in 
Duvalierist Haiti, whose bureaucrats had for decades exercised their sovereign right to plunder donor funds intended for their people. Even the most ardent government-to-government 'institution builders' had to back down and invite NGOs.

We agree, however, with the legitimacy of the second concern against premature beatification of the NGO-in-shining-armor. One of the authors (Murray), in an unpublished report for USAID/El Salvador, proposed a dichotomy between two types of NGOs: the ONGO, or 'operational NGO', with a bona-fide service track record, and the FONGO, the 'foraging NGO', that worldwide genus of parasitical profitoriented 'non-profit' group dedicated first and foremost to the foraging and capture of international donor funds. In the early 1980s, there were dozens of bonafide service-providing NGOs with whom we could work. In view of current (2003) international sanctions against the Haitian government, the NGO route continues to be the preferred project mode.

Tree programs in other political and cultural settings may eschew the NGO option. Few governments could have worked as efficiently as the NGOs of Haiti. But we will avoid doctrinaire generalizations. We simply pose a question for further professional debate. Under what conditions should agroforestry project funds be entrusted to a local government? And under what conditions should planners use every measure that is legally and politically feasible, as was done in Haiti, to protect a project against government interference?

\section{Pedagogues vs. partners: Assigning education its proper role}

Some would be puzzled that our project paradigm has no separate education component; education is instead a minor component under 'outreach'. The demotion is intentional. In the early years the project was almost 'anti-education'. In its emphasis on seedling supply, tree tenure, and harvest rights, the approach was a militant philosophical rejoinder to questionable pedagogical theories that viewed peasant knowledge deficits as the cause of Haiti's ecological problem and environmental education as the major solution. The educational component of the project was upgraded in later years with Creole-language manuals and training sessions in administration for CBOs. But we continue to surround education with two caveats. First, educational message-flows must be linked to material flows. They are analogous to user manuals that come with computers or printers. A manual is useless without access to the hardware. Equally useless are environmental education projects whose budgets finance the educational manuals but expect smallholders then to go forth and obtain seedlings on their own. Secondly, educational flows should be bi-directional, moving as frequently from farmer to project staff as vice-versa. While technical information regarding nursery and agronomic practices was valuable and necessary, the knowledge that staff in Haiti carried in their brains was, after 20 years of field immersion, more heavily influenced by farmer inputs than by lessons learned long ago in school. Stated differently, we abandoned the podium and the pulpit. We were neither pedagogues nor ecological preachers, but partners in a long-term joint venture, encapsulated by the Creole slogan used by the field staff 'Plantè se kolèg' (planters are colleagues). We suspect that in many other agroforestry settings as well, issues of seedling supply, tree tenure, and harvest rights are more critical than the mission of remedying presumed peasant knowledge deficits by itinerant environmental educators.

\section{Santa vs. Scrooge: The issue of seedling subsidy}

The preceding issues have been comfortably resolved in Haiti. The 'Santa vs. Scrooge' tensions - subsidyand-sustainability issues - have not. Seedling supply is the most hotly debated subsidy question: to gift or not to gift. Villagers in the 32 Nigerian settlements studied by Osembo (1987) stated that they would plant trees under three conditions: tree seedlings would be free of cost, farmers could interplant trees and food crops without losing crop yield, and that it would be possible to earn income from the trees. That verdict could have come straight from the mouth of Haitians. Hwang et al. (1994), Leakey and Tomich (1999), and Herrador and Dimas (2000), take similar stands justifying subsidies and incentives. But other observers have misgivings about the impacts of subsidies (Arnold and Dewees 1999; Bunch 1999; Napier and Bridges 2002).

Anti-subsidy voices in Haiti were varied. Hardliners wanted farmers to pay full price for seedlings. Soft-liners wanted a symbolic penny per-seedling, about $10 \%$ of production costs. (Soft-liners often alluded to character-building themes. People would be 'spoiled' if they get free handouts.). Had hard-liners prevailed, no trees would have been planted. Had softliners prevailed perhaps 1000 farmers per year all over Haiti would have bought 10 or 20 wood trees each, yielding a 20 -year total of 20000 households planting 
400000 trees (and that is probably a speculative overestimation). With our joint venture mode, in which farmers supplied land and labor and the project supplied a modest average \$20-per-participant seedling subsidy, 350000 households planted 65 million trees. In retrospect we now know with certitude that a 'character building' decision on our part to exact at least a penny per seedling would have been an exercise in institutional idiocy. It would have suppressed over 99\% of the tree planting that occurred with absolutely no sustainability benefits. A project in which peasants pay for $10 \%$ of the seedlings is no more sustainable than one in which the project simply donates seedlings.

We can go further and quantify the damage done by anti-subsidy interventions. Some 10 years into the project a USAID director opposed to subsidies ordered PADF, under threat of de-funding, to desist from purchasing and delivering free seedlings to farmers. If they want wood trees, let them pay full price. No farmers did, of course. This led to the shutting of the 36 NGO nurseries that had emerged during the previous decade with PADF as their sole or principal purchaser, and which had been pumping out about ten million seedlings a year onto peasant land. (Such anti-subsidy sentiment is often selective and whimsical. The same director who withheld free trees from villages continued to instruct his subordinates to endow the same villages with abundant flows of free contraceptives).

The seedling flow was reactivated under his successor, who reversed his order, but under hastily constructed new nurseries the volume never recuperated. The original nurseries had lost their investment in infrastructure and no longer trusted USAID or PADF. We can calculate that, had those nurseries not been closed, they would have distributed during the decade of the 1990s as many as 80 million, rather than 14 million, seedlings. At 200 trees per participating household, this 66 million-seedling gap translates into more than 300000 rural Haitian households who were blocked from initiating or repeating the planting of tree seedlings. An annual multi-million-seedling flow that had taken ten years to create and nurture was stopped by the dogmatic flick of an anti-subsidy pen.

Philosophical dogmatism divorced from empirical reality but linked to administrative power can indeed be destructive. One powerful empirical fact that should have been honestly confronted by an American agency before cutting off the free seedling flow to impoverished Haitians is the tree-subsidy policy of the U.S. government toward its own farmers. The U.S. Department of Agriculture has a na- tional cost-share program in the 2002 Farm Bill called the Forest Land Enhancement Program (FLEP) that provides up to $\$ 10000$ per landowner per year for tree plantation and management practices (http://www.fldof.com/Help/FLEP.html). FLEP is not unique, and was preceded by other similar programs, such as the Forest Incentive Program (FIP) and the Conservation Reserve Program, among others. If a U.S. farmer can receive $\$ 10000$ per year in tree subsidies without lethal damage to the American economy or to the moral character of the recipient, we would appreciate arguments as to why the same is not true of a one-shot \$20 seedling subsidy to a Haitian villager.

\section{The issue of sustainability}

Will farmers continue agroforestry once project support has ceased? The question must be broken down into two components. (1) Will they protect and manage coppice and volunteer seedlings? (2) Will they henceforth purchase wood seedlings commercially or begin producing them in their backyards? The answer to the first question is an empirically solid yes. We have already indicated not only that farmers have left some trees standing as a bank of value, but also that they have creatively managed coppice regrowth and volunteer seedlings long after project-termination.

We have no evidence, however, that they will on their own, without container subsidies, establish backyard wood-seedling nurseries and we doubt that they will purchase seedlings commercially. To our knowledge neither of these behaviors has occurred (in Haiti), nor have any studies addressed these specific questions. We know well that coppice and wildling management will sustain only a modest percentage of the trees for several years at most. Without new inputs of germplasm, plots that received trees are in danger of reverting eventually to their former treeless condition. No matter how attractive they are, the returns from tree planting are still too far down the road to compete with more immediate cash needs. This is as true for the prosperous American farmer who will not plant trees without a $\$ 10000$ per-annum subsidy program, as it is for the Haitian farmer who will perform amazing agroforestry feats with the modest $\$ 20$ seedling grant which our project supplied.

Are we declaring wood-tree planting to be impossible without subsidies? Of course not. Georgia Pacific, Weyerhaeuser, and similar companies have a long record of planting, managing, and harvesting wood trees without any public support. We can, in 
sanctimonious avoidance of subsidies, leave the regreening of the landscape to these powerful economic giants. If the goal, however, is to involve impoverished tropical smallholders in the transition to domesticated wood, in our view there is no magical mantra, no quick-fix educational or motivational gimmicks, that can circumvent the need for sustained public or philanthropic seedling support in the foreseeable future.

To conclude, in arguing for the approach used in Haiti, we are not peddling panaceas. The approach adopted here cannot by itself protect natural forests and cannot by itself provide total coverage of a watershed. It was not meant to. What it will do can be stated with simplicity and focus: It will enable local shifts into the domesticated production of the wood that was formerly scavenged from nature. We now know with certitude that a latent readiness to make this shift existed in Haiti. We believe that that same readiness for wood-tree planting exists in other world regions and other cultural settings as well, able to be activated on as massive a scale as was activated in Haiti. The catalyzing impact will come only if conservationist homilies and protectionist penalties are replaced with a rich supply of seedlings made available to villagers under the same tenure and market assumptions that govern other crops. The Haitian peasants have taught us a major lesson. We now know that it is possible, through anthropologically and technically sound project planning, to create the conditions by which even impoverished smallholders can participate in the exciting transition now occurring, as humans replicate the food-domestication achievements of their Neolithic ancestors and now bring even the wood tree itself into that subset of flora that humans plant, tend, and harvest.

\section{Acknowledgements}

The authors sincerely appreciate the candid comments and suggestions made by the reviewers, which greatly improved this chapter. Florida Agricultural Experiment Station Journal Series Number R-09895.

\section{End Notes}

1. Murray G. 1979. Terraces, trees, and the Haitian peasant: An assessment of 25 years of erosion control in rural Haiti. USAID, Port-au-Prince.
2. Murray G. 1981. Peasant tree planting in Haiti: A social soundness analysis. USAID, Port-au-Prince.

3. Smucker G. 1981. Trees and charcoal in Haitian peasant economy: A feasibility study of reforestation. USAID, Haiti.

4. Buffum W. 1985. Three years of tree planting in a Haitian mountain village: A socio-economic analysis. Pan American Development Foundation, Port-au-Prince.

5. Buffum W. and King W. 1985. Small farmer tree planting and decision making: Agroforestry extension recommendations. Pan American Development Foundation, Port-au-Prince.

6. Conway F.J. 1986a. The decision-making framework for tree planting in the Agroforestry Outreach Project. University of Maine Agroforestry Outreach Research Project, Port-au-Prince.

7. Conway F.J. 1986b. Synthesis of socioeconomic findings about participants in the USAID/Haiti Agroforestry Outreach Project. University of Maine Agroforestry Outreach Research Project, Port-au-Prince.

8. Lauwerysen H. 1985. Socioeconomic study in two tree-planting communities (St. Michel de L'Atalaye and Bainet). Pan American Development Foundation, Port-au-Prince.

9. Grosenick G. 1986. Economic evaluation of the Agroforestry Outreach Project. University of Maine Agroforestry Outreach Research Project, Port-au-Prince.

10. McGowan L.A. 1986. Potential marketability of wood products, rural charcoal consumption, peasant risk aversion strategies, and the harvest of AOP trees. University of Maine Agroforestry Outreach Research Project, Port-au-Prince.

11. Smucker G. 1988. Decisions and motivations in peasant tree farming: Morne-Franck and the PADF cycle of village studies. Pan American Development Foundation, Port-au-Prince.

12. Smucker G. and Timyan J. 1995. Impact of tree planting in Haiti: 1982-1995. Haiti Productive Land Use Systems Project, Southeast Consortium for International Development and Auburn University, Petionville, Haiti.

13. Some readers may wonder at the absence of a separate educational rubric as a key project component. This will be discussed below.

14. The project was also implemented by CARE in a separate region of Haiti, in the semi-arid Northwest.

15. Balzano A. 1986. Socio-economic aspects of forestry in rural Haiti. University of Maine Agroforestry Outreach Research Project, Port-au-Prince.

16. Balzano A. 1997. A Haitian community: ten years after. Presented to The Society for Anthropology in Community Colleges, 1997 Annual Meeting, Toronto, Canada, April 16-19, 1997.

\section{References}

Arnold J.E.M. and Dewees P.A.A 1999. Trees in managed landscapes: factors in farmer decision making. In: Buck L.E., Lassoie J.P. and Fernandes E.C. (eds). Agroforestry in Sustainable Agricultural Systems. CRC Press, Lewis Publishers, Boca Raton Florida, USA.

Ashby J.A., Alonso Beltrán J., del Pilar Guerrero M. and Fabio Ramos H. 1996. Improving the acceptability to farmers of soil conservation practices. J. Soil Water Conserv. 51: 309-312.

Balzano A. 1989. Tree-planting in Haiti: Agroforestry and rural development in a local context. Ph.D. dissertation, Rutgers University, USA.

Bannister M.E. and Josiah S.J. 1993. Agroforestry training and extension: the experience from Haiti. Agroforest Syst 23: 239-251. 
Bannister M.E. and Nair P.K.R. 2003. Agroforestry adoption in Haiti: the importance of household and farm characteristics. Agroforest Syst 57: 149-157.

Bannister M.E. and Nair P.K.R. 1990. Alley cropping as a sustainable technology for the hillsides of Haiti: experience of an agroforestry outreach project. Am J Alt Agr 5: 51-57.

Bunch R. 1999. Reasons for non-adoption of soil conservation technologies and how to overcome them. Mt Res Dev 19: 213-220.

Ehrlich M., Conway F., Adrien N., LeBeau F., Lewis L., Lauwerysen H., Lowenthal I., Mayda Y., Paryski P., Smucker G., Talbot J. and Wilcox E. 1985. Haiti Country Environmental Profile: a field study. USAID, Port-au-Prince, Haiti.

Escobar A. 1991. Anthropology and the development encounter: The making and marketing of development anthropology. Am Ethnol 18: 658-682.

Ferraro G. 1998. Cultural Anthropology: An Applied Perspective (third edition). West/Wadsworth, New York. 397 pp.

Garcia J.N., Gerrits R.V. and Cramb R.A. 2002. Adoption and maintenance of contour bunds and hedgerows in a dynamic environment. Experience in the Philippine uplands. Mt Res Dev 22: 10-13.

Harris M. and Johnson O. 2000. Cultural Anthropology (5th Edition). Allyn and Bacon, Boston, 374 pp.

Herrador D. and Dimas L. 2000. Payment for environmental services in El Salvador. Mt Res Dev 20: 306-309.

Holdridge L.R. 1947. Determination of world plant formations from simple climatic data. Science 105: 367-368.

Hwang S.W., Alwang J. and Norton G.W. 1994. Soil conservation practices and farm income in the Dominican Republic. Agr Syst 46: 59-77.

Leakey R.B. and Tomich T.P. 1999. Domestication of tropical trees: from biology to economics and policy, pp. 319-338. In: Buck L.E., Lassoie J.P. and Fernandes E.C. (eds). Agroforestry in Sustainable Agricultural Systems. CRC Press, Lewis Publishers, Boca Raton Florida, USA.

Murray G. 1984. The wood tree as a peasant cash crop: An anthropological strategy for the domestication of energy, pp. 141160. In: Foster C.R. and Valdman A. (eds). Haiti - Today and Tomorrow. University Press of America, Lanham, MD.

Murray G. 1987. The domestication of wood in Haiti: A case study in applied evolution, pp. 223-242. In: Wulff R.M. and Fiske
S.J. (eds). Anthropological Praxis: Translating Knowledge into Action. Westview Press, Boulder CO.

Nair P.K.R. 1993. An Introduction to Agroforestry. Kluwer, Dordrecht, The Netherlands, 499 pp.

Nanda, S. and Warms R. 1998. Cultural Anthropology. West/Wadsworth, New York, 429 pp.

Napier T.L. and Bridges T. 2002. Adoption of conservation production systems in two Ohio watersheds: a comparative study. J Soil Water Conserv 57: 229-235.

Osembo G.J. 1987. Smallholder farmers and forestry development: a study of rural land-use in Bendel, Nigeria. Agr Syst 24: 31-51.

Peoples J. and Bailey G. 1997. Humanity: An Introduction to Cultural Anthropology. West/Wadsworth, New York, 446 pp.

Podolefsky A. and Brown P.J. (eds) 1989. Applying Anthropology: An Introductory Reader. Mountain View, Mayfield, CA, 324 pp.

Robbins R. 1993. Cultural Anthropology: A Problem-based Approach. F.E. Peacock Publisher, Itasca, IL, 222 pp.

Rogozinsky, J. 2000. A Brief History of the Caribbean: From the Arawak and Carib to the Present (Revised Edition). Penguin Putnam (Plume), New York. 415 pp.

Simons A.J. and Leakey R. 2004. Tree domestication in agroforestry in the tropics (this volume).

Smucker G.R., White T.A. and Bannister M.E. 2002. Land tenure and the adoption of agricultural technology in Haiti, pp. 119146. In: Meinzen-Dick R., Knox A., Place F. and Swallow B. (eds). Innovation in Natural Resource Management: The Role of Property Rights and Collective Action in Developing Countries. Johns Hopkins University Press for the International Food Policy Research Institute, Baltimore, MD.

Timyan J. 1996 Bwa yo: Important Trees of Haiti. South-East Consortium for International Development, Washington, D.C., $418 \mathrm{pp}$.

Weil T.E., Black J.K., Blutstein H.I., Johnston K.T., McMorris D.S. and Munson F.P. 1973. Area Handbook for Haiti. U.S. Government Printing Office, Washington, DC. 189 pp.

Zobel B.J. and Talbert J.T. 1984. Applied Forest Tree Improvement. John Wiley \& Sons, Inc., New York, 505 pp.

Zuvekas C. 1979. Land tenure in Haiti and its policy implications: A survey of the literature. Soc Econ Stud 28: 1-30. 